\title{
A Bioinformatics Analysis of Memory Consolidation Reveals Involvement of the Transcription Factor c-Rel
}

\author{
Jonathan M. Levenson, ${ }^{1}$ Sangdun Choi, ${ }^{4}$ Sun-Young Lee, ${ }^{4}$ Yun Anna Cao, ${ }^{4}$ Hyung Jin Ahn, ${ }^{2}$ Kim C. Worley, ${ }^{3}$ \\ Marina Pizzi, ${ }^{5}$ Hsiou-Chi Liou, ${ }^{6}$ and J. David Sweatt ${ }^{1}$ \\ ${ }^{1}$ Division of Neuroscience, ${ }^{2}$ Department of Molecular Physiology and Biophysics, and ${ }^{3}$ Human Genome Sequencing Center, Baylor College of Medicine, \\ Houston, Texas 77030, ${ }^{4}$ Division of Biology, California Institute of Technology, Pasadena, California 91125, ${ }^{5}$ Division of Pharmacology and Experimental \\ Therapeutics, Department of Biomedical Sciences and Biotechnologies, School of Medicine, University of Brescia, 25123 Brescia, Italy, and ${ }^{6}$ Department of \\ Microbiology and Immunity, Weill Medical College of Cornell University, New York, New York 10021
}

Consolidation of long-term memory (LTM) is a complex process requiring synthesis of new mRNAs and proteins. Many studies have characterized the requirement for de novo mRNA and protein synthesis; however, few studies have comprehensively identified genes regulated during LTM consolidation. We show that consolidation of long-term contextual memory in the hippocampus triggers altered expression of numerous genes encompassing many aspects of neuronal function. Like contextual memory formation, this altered gene expression required NMDA receptor activation and was specific for situations in which the animal formed an association between a physical context and a sensory stimulus. Using a bioinformatics approach, we found that regulatory elements for several transcription factors are over-represented in the upstream region of genes regulated during consolidation of LTM. Using a knock-out mouse, we found that $c$-rel, one of the transcription factors identified in our bioinformatics study, is necessary for hippocampus-dependent long-term memory formation.

Key words: memory; hippocampus; microarray; bioinformatics; $\mathrm{NF} \kappa \mathrm{B}$; transcription factor

\section{Introduction}

Very long-lasting changes in physiology, such as those changes underlying long-term memory (LTM), require changes in gene expression. Early in the study of memory, it was discovered that transcription is required for the formation of LTM in a wide variety of organisms (Abel and Kandel, 1998; Milner et al., 1998). Over the last two decades, tremendous progress has been made in elucidating the specific molecular mechanisms underlying LTM (Abel and Kandel, 1998). In a broad range of organisms, early activation of various signal transduction cascades eventually leads to activation of the cAMP-dependent protein kinase and the Ras-MEK-ERK/MAPK [Ras-MAP kinase kinase-extracellular signal-regulated kinase/mitogen-activated protein (MAP) kinase] cascade, resulting in the regulation of transcription through the transcription factor cAMP response element (CRE)-binding protein (CREB) (Adams and Sweatt, 2002; Silva, 2003). CREBmediated early transcription is then thought to activate a subsequent wave of transcription, possibly mediated by the C/EBP (CCAAT/enhancer binding protein) family of transcription factors, which results in consolidation of LTM (Abel and Kandel, 1998; Milner et al., 1998).

Received Dec. 22, 2003; revised Feb. 5, 2004; accepted March 3, 2004

This work was supported by National Institute of Mental Health Grant MH57014 (J.D.S.) and Department of Energy Grant DE FG03-95ER62097 (K.C.W.).

Correspondence should be addressed to J. David Sweatt, Division of Neuroscience, Baylor College of Medicine, One Baylor Plaza, Houston, TX 77030. E-mail: jsweatt@bcm.tmc.edu.

DOI:10.1523/JNEUROSCI.5646-03.2004

Copyright $\odot 2004$ Society for Neuroscience $\quad$ 0270-6474/04/243933-11\$15.00/0
Several model systems have been developed to facilitate the study of LTM formation, and, of late, contextual fear conditioning in rodents has served as a fruitful model for the study of LTM formation in mammals. Contextual fear conditioning consists of a brief training period that pairs a physical context with a noxious stimulus (Fanselow, 2000). The paired contextual fear training paradigm results in the formation of a robust and enduring fear of the physical context (Fanselow, 2000). Formation and retrieval of long-term contextual fear memory requires the hippocampus (Phillips and LeDoux, 1992; Fanselow, 2000).

The properties of long-term contextual fear memory are similar to the general properties of LTM formation. Formation of long-term contextual fear memory requires engagement of NMDA receptors (NMDARs), the ERK/MAPK signaling cascade, and ultimately regulation of transcription (Atkins et al., 1998). Formation of contextual fear memory requires the hippocampus, and gene expression within the hippocampus appears to be required for formation and retrieval of long-term contextual fear memory (Hall et al., 2001; Ressler et al., 2002). The transcription factors CREB and C/EBP have been implicated in the regulation of transcription in the hippocampus during formation of longterm contextual fear memory (Bourtchuladze et al., 1994; Impey et al., 1998; Taubenfeld et al., 2001). Thus, modulation of gene expression within the hippocampus, possibly leading to increased synaptic efficacy, appears to be required for formation of long-term contextual fear memory.

Gene expression represents the integrated action of several regulatory elements present within and nearby the gene. There- 
fore, genes regulated in response to a stimulus represent a molecular "readout" of the various signaling pathways activated and the subsequent transcription factors and regulatory elements recruited to modulate gene transcription. In the pursuit of the molecular basis for memory formation, several studies have identified numerous genes that are regulated during formation of LTM in many different organisms (Abel and Kandel, 1998; Milner et al., 1998). Surprisingly, only a few transcription factors and their associated regulatory elements have been implicated in LTM formation. Recent studies investigating the regulation of gene expression in various regions of the mammalian brain have begun to use high-density microarray technology (Irwin, 2001; Mody et al., 2001; Cavallaro et al., 2002; Leil et al., 2002; Matzilevich et al., 2002). In this study, we used high-density oligonucleotide arrays to comprehensively screen a significant portion of the murine genome for gene expression during consolidation of contextual fear memory in area CA1 and the dentate gyrus of the hippocampus. Genes identified in our profiling experiments were specifically regulated by a paired training paradigm, and most changes were dependent on NMDAR function. Using the list of consolidation-associated genes in concert with bioinformatic analysis of the newly available murine genome database, several memory consolidation-associated regulatory elements were identified that had never before been implicated in formation of LTM. Finally, we show that one of the newly implicated "memory" regulatory elements, c-rel, is involved in hippocampusdependent long-term memory formation.

\section{Materials and Methods}

Animals. C57BL/6J (4-8 weeks old) mice were obtained from the Baylor College of Medicine mouse breeding facility. $c$ - rel knock-out mice (Liou et al., 1999) (c-rel ${ }^{-/-}$, C57BL/6 background strain) were used between 4 and 12 weeks of age. Knock-out mice were generated by mating homozygous males and females. Age-matched C57BL/6 $\mathrm{c}-\mathrm{rel}^{+/+}$mice from the same colony were used as wild-type (WT) controls. Animals were housed under a $12 \mathrm{hr}$ light/dark cycle and allowed access to food and water ad libitum. Animals were allowed to acclimate to the laboratory $1-2 \mathrm{hr}$ before use. All mice used in this study were male. All experiments were performed in accordance with the Baylor College of Medicine Institutional Animal Care and Use Committee and with national regulations and guidelines.

Contextual fear conditioning. Animals were placed into the fear conditioning apparatus (Med Associates, E. Fairfield, VT), which was housed in a sound attenuation chamber, 2 min before receiving a $1 \mathrm{sec}$ electric shock $(0.5 \mathrm{~mA})$ delivered through a floor grid. The 2 min-1 sec shock paradigm was repeated for a total of three shocks. Animals were removed from the training chamber $1 \mathrm{~min}$ after receiving the last shock. Latent inhibition controls were performed by placing the animals into the chamber $2 \mathrm{hr}$ before receiving the shock paradigm outlined above and removing the animals from the training chamber $1 \mathrm{hr}$ after receiving the last shock. For experiments involving MK-801, animals were injected 1 $\mathrm{hr}$ before receiving the standard, contextual fear conditioning paradigm [5 $\mu \mathrm{l}(60 \mu \mathrm{g} / \mathrm{ml})$ of MK-801 per gram of body weight]; control animals received an injection of saline. Injection of MK-801 had no affect on the threshold current required to elicit flinching, vocalization, or jumping behaviors from animals (data not shown). Every microarray experiment consisted of 10 animals divided into two groups: "naive" and "fear conditioned." In the case of the latent inhibition experiments, the two groups were "naive" and "latent inhibition." For the MK-801 experiments, the groups were "saline-naive" and "MK-801-fear conditioned." Therefore, each sample of tissue collected from animals that underwent an experimental manipulation had a time-matched naive control sample. Hybridization and analysis of experimental and matched control samples was performed simultaneously to two separate microarrays. $\log _{2}$ ratios were computed by comparing experimental samples with matched control samples. Contextual fear conditioning experiments were performed three independent times. Latent inhibition and MK-801 experiments were performed once.

RNA extraction. Animals were killed via cervical dislocation at various times after contextual fear conditioning (1-6 hr). Hippocampi were removed from the brain, microdissected to isolate area CA1 and the dentate gyrus, and immediately frozen. Tissue from four to five animals was pooled per experiment. RNA was isolated within 3 weeks of collection using TriZol (Invitrogen, San Diego, CA).

cDNA synthesis. For the Affymetrix (Santa Clara, CA) array, firststrand cDNA was synthesized by incubating $5 \mu \mathrm{g}$ of total RNA with $1 \mu \mathrm{l}$ of $100 \mathrm{pmol} / \mu \mathrm{l} \mathrm{T} 7 \mathrm{oligo}-\mathrm{dT}$ at $70^{\circ} \mathrm{C}$ for $10 \mathrm{~min}$, followed by a subsequent incubation with $4 \mu \mathrm{l}$ of $5 \times$ reverse transcriptase buffer, $2 \mu \mathrm{l}$ of $0.1 \mathrm{M}$ DTT, $1 \mu \mathrm{l}$ of $10 \mathrm{~mm} \mathrm{dNTP}$, and $1 \mu \mathrm{l}$ of $200 \mathrm{U} / \mu \mathrm{l}$ Superscript II at $42^{\circ} \mathrm{C}$ for $1 \mathrm{hr}$. Second-strand cDNA synthesis begins with the addition of $30 \mu \mathrm{l}$ of $5 \times$ second-strand buffer, $3 \mu \mathrm{l}$ of $10 \mathrm{~mm} \mathrm{dNTP}, 4 \mu \mathrm{l}$ of $10 \mathrm{U} / \mu \mathrm{l}$ Escherichia coli DNA polymerase I, $1 \mu \mathrm{l}$ of $10 \mathrm{U} / \mu \mathrm{l}$ E. coli DNA ligase, $1 \mu \mathrm{l}$ of $2 \mathrm{U} / \mu \mathrm{l}$ RNase $\mathrm{H}$, and $91 \mu \mathrm{l}$ of DEPC water, followed by incubation at $16^{\circ} \mathrm{C}$ for 2 hr. After incubation, $2 \mu \mathrm{l}$ of T4 DNA polymerase $(5 \mathrm{U} / \mu \mathrm{l})$ was added to the mixture, followed by $5 \mathrm{~min}$ incubation at $16^{\circ} \mathrm{C}$. The sample was immediately placed on ice for $5 \mathrm{~min}$ and then centrifuged briefly before the addition of $7.5 \mu \mathrm{l}$ of RNA digestion buffer $(1 \mathrm{~m} \mathrm{NaOH}$ and $2 \mathrm{~mm}$ EDTA, $\mathrm{pH} 8.0$ ) and the subsequent $10 \mathrm{~min}$ incubation at $65^{\circ} \mathrm{C}$. After the sample was cooled, $160 \mu \mathrm{l}$ of 25:24:1 phenol/chloroform/isoamyl alcohol was added to the mixture. The mixture was vortexed and immediately transferred to a phase lock gel tube, followed by a 3 min centrifugation at $12,000 \times g$. After centrifugation, $75 \mu \mathrm{l}$ of $7.5 \mathrm{M}$ ammonium acetate and $500 \mu \mathrm{l}$ of $100 \%$ ethanol $\left(-20^{\circ} \mathrm{C}\right)$ were added to the upper phase. The sample was then mixed and centrifuged immediately at $12,000 \times g$ for 20 $\mathrm{min}$ at room temperature. The supernatant was removed, and the pellet was washed using $80 \%$ ethanol $\left(-20^{\circ} \mathrm{C}\right)$ and $100 \%$ ethanol $\left(-20^{\circ} \mathrm{C}\right)$. The dried pellet was then dissolved in $22 \mu \mathrm{l}$ of DEPC water and stored at $-20^{\circ} \mathrm{C}$. For the Caltech $16 \mathrm{~K}$ oligonucleotide array, the Agilent (Palo Alto, CA) Fluorescent Linear Amplification kit was used. Both first- and second-strand cDNA were synthesized by incubating $3 \mu \mathrm{g}$ of total RNA with $5 \mu \mathrm{l}$ of $\mathrm{T} 7$ promoter primer in DEPC water at $65^{\circ} \mathrm{C}$ for $10 \mathrm{~min}$, followed by a subsequent incubation with $4 \mu \mathrm{l}$ of $5 \times$ first-strand buffer, $2 \mu \mathrm{l}$ of $0.1 \mathrm{~m} \mathrm{DTT}, 1 \mu \mathrm{l}$ of $10 \mathrm{~mm} \mathrm{dNTP}, 1 \mu \mathrm{l}$ of $200 \mathrm{ng} / \mu \mathrm{l}$ random hexamers, $1 \mu \mathrm{l}$ of $200 \mathrm{U} / \mu \mathrm{l}$ c-Moloney murine leukemia virus-reverse transcriptase, $0.5 \mu \mathrm{l}$ of $40 \mathrm{U} / \mu \mathrm{l}$ RNaseOUT, and $1 \mu \mathrm{l}$ of Triton X-100 at $40^{\circ} \mathrm{C}$ for $4 \mathrm{hr}$.

In vitro transcription. To synthesize cRNA from the double-stranded cDNA for the Affymetrix array, the BioArray High-Yield RNA Transcript Labeling kit (Enzo) was used. Biotin-labeled CTP and UTP (Enzo) were used to label the cRNA. After in vitro transcription, cRNA was purified using RNaeasy Mini kit (Qiagen, Hilden, Germany). To synthesize cRNA from double-stranded cDNA for the Caltech array, the Fluorescent Linear Amplification kit (Agilent) was used. Cyanine 3-CTP or cyanine 5-CTP (Agilent) was used to label the cRNA. After in vitro transcription, cRNA was purified using RNeasy Mini kit (Qiagen).

Hybridization. To hybridize labeled cRNA onto the Affymetrix array, cRNA was first fragmented by mixing $20 \mu \mathrm{g}$ of cRNA (in $32 \mu \mathrm{l}$ ) with $8 \mu \mathrm{l}$ of $5 \times$ fragmentation buffer and $40 \mu \mathrm{l}$ of RNase-free water. The mixture was then incubated at $94^{\circ} \mathrm{C}$ for $35 \mathrm{~min}$ and placed on ice after incubation. The hybridization mixture was prepared by mixing $10 \mu \mathrm{g}$ of fragmented cRNA (half of the initial mixture) with $3.3 \mu \mathrm{l}$ of $3 \mathrm{~nm}$ control oligonucleotide B2, $10 \mu \mathrm{l}$ of $20 \times$ eukaryotic hybridization controls (bioB, bioC, bioD, cre), $2 \mu \mathrm{l}$ of $10 \mathrm{mg} / \mathrm{ml}$ herring sperm DNA, $2 \mu \mathrm{l}$ of $50 \mathrm{mg} / \mathrm{ml}$ acetylated BSA, $100 \mu \mathrm{l}$ of $2 \times$ hybridization buffer, and, last, enough DEPC water to make a final volume of $200 \mu$ l. During array equilibration, the hybridization mixture was heated to $99^{\circ} \mathrm{C}$ for $5 \mathrm{~min}$ in a heat block, followed by $5 \mathrm{~min}$ incubation at $45^{\circ} \mathrm{C}$. After incubation, the hybridization mixture was spun at maximum speed in a microcentrifuge for $5 \mathrm{~min}$ to remove any insoluble material. Appropriate volume of the hybridization mixture was added to the probe array. The probe array was subsequently hybridized at $45^{\circ} \mathrm{C}$, rotating at $60 \mathrm{rpm}$, for $16 \mathrm{hr}$. After hybridization, the probe array was washed using the GeneChip Fluidics Station 400 (Affymetrix). To hybridize labeled cRNA onto the Caltech array, 10 $\mu \mathrm{g}$ of cyanine 3-dCTP-labeled cRNA and $10 \mu \mathrm{g}$ of cyanine 5-dCTPlabeled cRNA were combined with $2.5 \mu \mathrm{l}$ of Mouse Cot-1 DNA (Invitro- 
gen), $2.5 \mu \mathrm{l}$ of deposition control target (Operon), and $12.5 \mu \mathrm{l}$ of $2 \times$ hybridization buffer (Agilent). The mixture was boiled for $2 \mathrm{~min}$ and centrifuged at $12,000 \times g$ for $3 \mathrm{~min}$. Approximately $24 \mu \mathrm{l}$ of the resulting mixture was applied to the array and hybridized at $60^{\circ} \mathrm{C}$ for $17 \mathrm{hr}$. After hybridization, the array was washed several times with solution I $(0.5 \times$ SSC, $0.01 \%$ SDS, and $1 \mathrm{~mm}$ DTT in DEPC water), solution II ( $0.25 \times$ SSC, $0.01 \%$ SDS, and $1 \mathrm{~mm}$ DTT in DEPC water), and solution III $(0.06 \times$ SSC and $1 \mathrm{mM}$ DTT in DEPC water), respectively.

Array analysis. The array was scanned, and information was extracted using the GeneChip Expression Analysis program (Affymetrix). The output file contained the raw signals of the test and reference samples and the $\log _{2}$ ratio representing the fold differences between the test and reference samples. The analysis program gives a present/absent $(\mathrm{P} / \mathrm{A})$ call for each spot on the array based on a predetermined signal-to-noise ratio, along with a not changed/increase/marginal increase/decrease/marginal decrease (NC/I/MI/ $\mathrm{D} / \mathrm{MD}$ ) call for the two-array comparison. The genes that had an NC/ $\mathrm{MI} / \mathrm{MD}$ call were filtered out. It should be noted that our RNA samples were derived from tissue pooled from four to five animals, minimizing the potential contaminating effect of inter-animal variability. Moreover, experiments investigating consolidation of memory after exposure to the paired training paradigm were independently replicated three times. In our final identification of consolidation-associated genes, genes whose means were not $>2$ SDs from no change were excluded from our statistical analysis. Variance-based filtering was used to limit the number of statistical comparisons made and increase the overall power of our analyses. Filtering based on variance reduced the total number of statistical comparisons that were made from 99,360 to only 72 . Statistical significance was determined using a $t$ test for each gene, with a significance level of $p<0.01$. Of a total of 72 comparisons, one would expect one false positive result at a significance level of 0.01 . The false discovery rate (Benjamini et al., 2001) (expected false positives/ observed positives) of 0.014 for our dataset is well within the allowable limits for most biological studies (0.05). The regulation of six genes was independently verified by quantitative real-time reverse transcription-PCR (RTQPCR) (see Fig. 2). Use of high-density oligonucleotide arrays to study regulation of gene expression has been characterized extensively in previous publications (Choi et al., 2001). All microarray data has been submitted to the GEO database maintained by the National Center for Biotechnology (NCBI) (Edgar et al., 2002) (http://www.ncbi.nlm.nih.gov/ geo/) and can be accessed using the following accession numbers: GSM4493-GSM4507, GSM4509-GSM4514, GSM4516-GSM4523, GSM4525-GSM4529, GSM4531-GSM4533, GSM4535-GSM4540, GSM4542-GSM454546, GSM4548-GSM4551, GSM4553-GSM4558, GSM4560-GSM4563, GSM4565-GSM4567, and GSM4619-GSM4634.

Mapping of murine genes to human genome. Human homologs of murine genes were determined primarily using Homologene found at the NCBI website (http://www.ncbi.nlm.nih.gov/HomoloGene/). Genes that had no apparent human homolog using Homologene were submitted to either the Ensemble (http://www.ensembl.org/) or Mouse Genome Informatics (http://www.informatics.jax.org/) databases to identify potential homologous genes.

Transcription factor analysis. Upstream sequence information was obtained from either Celera Genomic Database (Beth Israel Deaconess Medical Center, Boston, MA) or the University of California, Santa Cruz Genome Browser (http://www.genome.ucsc.edu/). Two criteria were used to match each gene to its sequence. First, the gene information (chromosome location, gene name, and unigene identification number) between the probe on the microarray and the sequence in the database had to match. Second, the probe sequence $(200-300 \mathrm{bp})$ had to align perfectly to either the mRNA or genomic sequence (some Affymetrix probes hybridize to the $3^{\prime}$ untranslated region, $\sim 0.5 \mathrm{~kb}$ downstream of the coding region of the targeted gene). After obtaining all of the genomic sequence information, $1000 \mathrm{bp}$ of the immediate upstream sequence was used to search for transcription factor binding sites (MatInspector software; Genomatix, Munich, Germany). Two control experiments were performed to verify that the transcription factors identified in the consolidation-associated genes were unique to memory consolidation. The first control experiment entailed identifying regulatory elements enriched in 35 random genes that had detectable expression in all of the control (naive) oligonucleotide arrays. Therefore, this first set of control genes represents a population of mRNAs that are normally expressed in the hippocampus but are not regulated during memory consolidation. The second control experiment identified regulatory elements enriched in a set of 43 genes that were found not to be regulated by fear conditioning. The second list of genes included only four genes that had detectable levels of hybridization in the hippocampus. Therefore, the second set of control genes represents a random population of mRNAs that are present on the Affymetrix oligonucleotide array. All mRNAs randomly selected had to be known genes whose sequence was present in either the Celera or Ensemble databases.

Behavioral analysis of $\mathrm{c}-\mathrm{rel}^{-1-}$ mice. Behavioral analyses began when the mice were $4-7$ weeks old. The open-field task was performed using a $37 \mathrm{~cm}^{2}$ Opto-Varimax chamber (Columbus Instruments, Columbus, $\mathrm{OH})$. Animals were placed into the center of the chamber, and locomotor activity was monitored for $15 \mathrm{~min}$. The thermal sensitivity test was performed using a Hotplate Analgesia Meter (Columbus Instruments) at $53^{\circ} \mathrm{C}$. The apparatus was allowed to equilibrate for $4 \mathrm{hr}$ before data collection. Latency to lick hindpaw (in seconds) was recorded for each animal. Animals were removed from the chamber after a hindpaw lick or $30 \mathrm{sec}$. Animals that did not lick their hindpaw were scored as $30 \mathrm{sec}$. Contextual fear conditioning was performed as outlined above. Associative fear conditioning was performed as follows. Animals were placed into the training chamber for $3 \mathrm{~min}$. The animal was then exposed to a 30 sec white-noise tone, followed immediately by a footshock $(2 \mathrm{sec}, 0.5$ $\mathrm{mA}$ ). After $1.5 \mathrm{~min}$, another tone-shock pairing was administered. Animals were removed $1.5 \mathrm{~min}$ after the last tone-shock pairing. Freezing behavior was measured $24 \mathrm{hr}$ after training by placing the animals into a novel, clear plastic box for $6 \mathrm{~min}$. The white-noise cue was present for the last $3 \mathrm{~min}$ of the testing period. Animals were exposed to only one fear conditioning task, either contextual or associative. The behavioral analyses were performed in the order described, with at least 1 week resting period between each test.

Statistical analyses. Comparison of freezing behavior after exposure to either the paired or unpaired training paradigm was made using a $t$ test. The effect of MK-801 on freezing behavior was analyzed using the Kruskal-Wallis test, with post hoc comparisons made using Dunn's multiple comparison test. Product-moment correlation was used to investigate relationships between regulation of gene expression by the paired training paradigm and either the unpaired training paradigm or injection of MK-801. Analysis of clustering of genes by chromosome was performed using a $\chi^{2}$ test comparing known representation of each chromosome on the array (expected) with representation of each chromosome in our data set (observed). Significant grouping within a chromosome was determined by calculating the $95 \%$ confidence interval of the mean observed/expected ratio of the entire chromosome grouping dataset. Both the mouse and human chromosome grouping datasets had distributions that were not significantly different from a Gaussian. Regulatory elements were considered significant if they were within the top fifth percentile of their respective frequency histograms, and they were not present in either of the two lists of randomly selected mRNAs present on the oligonucleotide array. The behavioral characterization of $c-\mathrm{rel}^{-1-}$ mice in the open-field, thermal sensitivity, and fear conditioning paradigms was analyzed via Student's $t$ test, except for freezing behavior assessed $24 \mathrm{hr}$ after training in the associative fear task, which was analyzed via one-way ANOVA with post hoc tests performed using Tukey's method. Significance for all tests was set at $p<0.05$.

\section{Results}

Contextual fear conditioning requires pairing of exposure to a novel context [conditioned stimulus (CS)] with an aversive stimulus (Fanselow, 2000) [unconditioned stimulus (US)] (Fig. 1A). Exposure of animals to a paired contextual fear conditioning paradigm resulted in significant enhancement of freezing behavior (mean \pm SEM, $69 \pm 7 \% ; n=6$ ) when assessed in the CS $24 \mathrm{hr}$ after training (Fig. $1 \mathrm{~B}$ ). However, when the CS was presented $2 \mathrm{hr}$ before the US during the training session (latent inhibition control), animals displayed significantly less freezing behavior (mean \pm SEM, $24 \% \pm 12 ; n=6$ ) when placed into the training 
A

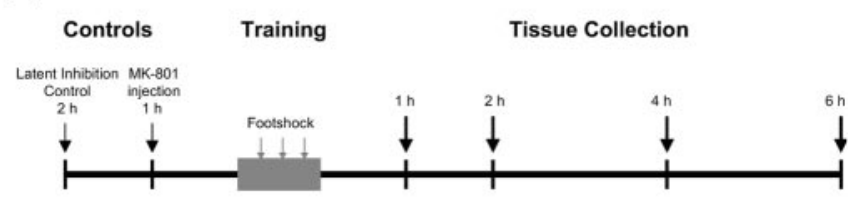

B
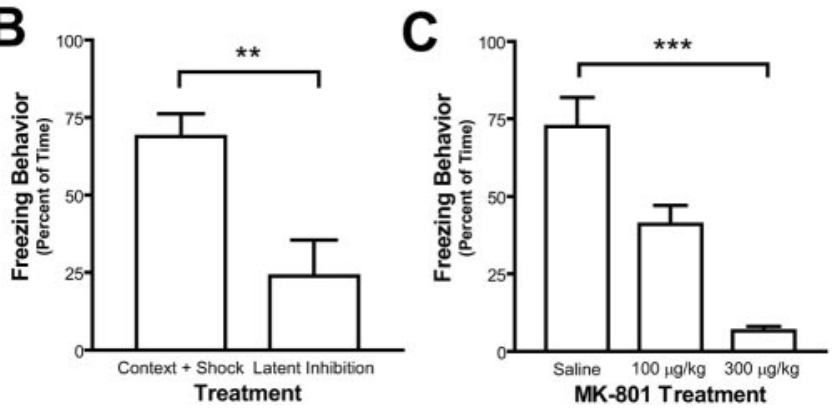

Figure 1. Requirements for formation of contextual fear memory. A, Diagram illustrating the various behavior paradigms used in these studies. For a complete description, see Material and Methods. B, Animals exposed to the paired fear conditioning training paradigm (Context + Shock) exhibited a high degree of freezing behavior when placed into the training context $24 \mathrm{hr}$ later. Animals exposed to the latent inhibition paradigm (Latent Inhibition) exhibited no significant freezing behavior when tested $24 \mathrm{hr}$ later. ${ }^{* *} p<0.01$ indicates that means were significantly different. C, Animals were injected with either saline or MK-801 $1 \mathrm{hr}$ before exposure to the paired fear conditioning paradigm. MK-801 significantly inhibited display of freezing behavior in a dose-dependent manner when animals were placed into the context $24 \mathrm{hr}$ after training. ${ }^{* *} p<0.001$ indicates that means were significantly different. In all graphs, bars represent mean data from six animals; error bars indicate SEM.

context 24 hr later (Fig. $1 B)(t=3.26$; df $=10 ; p<0.01)$. Additionally, formation of contextual fear memories required the action of NMDARs. Intraperitoneal injection of the NMDAR antagonist MK-801 significantly attenuated acquisition of CSinduced freezing behavior when assessed $24 \mathrm{hr}$ after training (Fig. 1C) $\left(H_{(2,16)}=13.57 ; p<0.005\right)$. Similar to other studies (Fanselow et al., 1994; Impey et al., 1998), formation of longterm contextual fear memory, as induced by our protocols, required the paired presentation of a novel contextual CS plus US and NMDAR function.

Using an Affymetrix high-density oligonucleotide array (U74Av2), expression of 12,420 genes was monitored in area CA1 and also in the dentate gyrus of the hippocampus during times corresponding to the consolidation phase of long-term contextual fear memories (Bourtchouladze et al., 1998; Igaz et al., 2002). Approximately 4000 of 12,420 oligonucleotides present on the array had detectable hybridization in both area CA1 and the dentate gyrus (data not shown). We assayed four different times after exposure to the contextual fear conditioning paradigm (Fig. 1A) and observed that expression of 38 mRNAs was significantly modulated in area CA1 (supplementary Table 1, available at www.jneurosci.org), and 31 mRNAs were modulated in the dentate gyrus (supplementary Table 2). These genes were identified on the basis of their robust regulation over three independent experiments. The statistical procedures used to identify consolidation-associated changes in gene expression are outlined in Materials and Methods; however, it should be noted that the false discovery rate (Benjamini et al., 2001) of our study was estimated at 0.014 , which translates to, at most, one false positive result in our list of consolidation-associated genes. Independent verification of our procedures has been performed previously (Choi et al., 2001). Additional verification for changes in mRNA

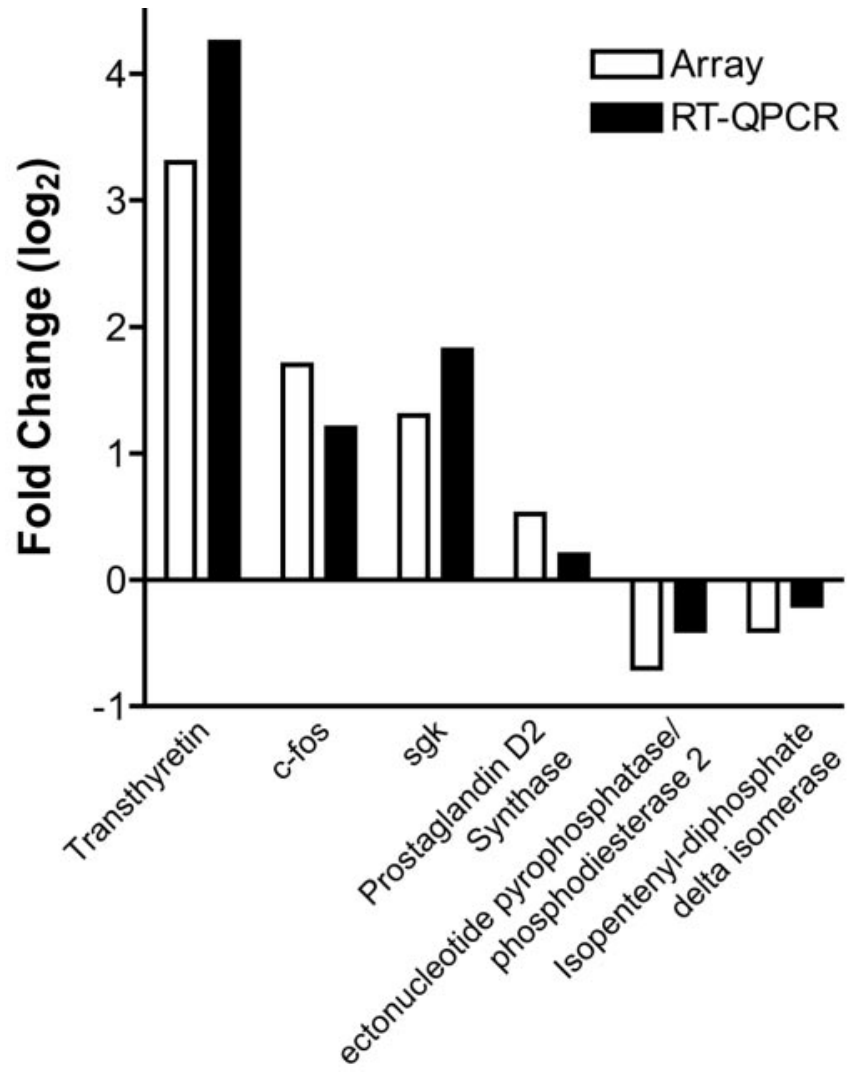

Figure 2. Verification of microarray results. Six genes whose expression was regulated during consolidation of LTM (transthyretin, c-fos, sgk, prostaglandin D2 synthase, ectonucleotide pyrophosphatase/phosphodiesterase 2, and isopentenyl-diphosphate $\delta$ isomerase) were selected for independent verification via real-time RT-QPCR. Changes in gene expression measured using microarrays were virtually identical to changes measured using RT-QPCR. Open bars represent data obtained using oligonucleotide arrays, and filled bars represent data obtained using RT-QPCR.

expression of six genes identified via microarray was performed using real-time QPCR (Fig. 2). Of the six genes, four were increases and two were decreases. Moreover, two of the genes verified, one increase and one decrease, were relatively small in magnitude. It should be noted that two of the genes verified by RT-QPCR, transthyretin and sgk (serum glucocorticoid regulated kinase), have been implicated in formation of LTM in the hippocampus (Stein and Johnson, 2002; Tsai et al., 2002) but have never been shown to be regulated during either induction or consolidation of long-term contextual fear memory in the hippocampus. Therefore, the verification of changes in these genes indicate that the techniques used in the present study are capable of detecting a wide range of changes in the expression of RNAs that have never before been quantified during the formation of LTM.

Several different types of genes were regulated, including transcription factors, signaling molecules, and metabolic enzymes (supplementary Tables 1, 2). The temporal pattern of gene regulation in both the dentate gyrus and area CA1 included an initial burst of gene upregulation ( $1 \mathrm{hr}$ ) that was followed by a period of gene repression $(2-4 \mathrm{hr}$ ) (Fig. $3 A, B)$. The next $4-6 \mathrm{hr}$ were marked by a second wave of increases in gene expression (Fig. $3 A, B)$. This suggests that the general molecular program for consolidation of LTM is similar between both area CA1 and the dentate gyrus of the hippocampus, although the specific molecules regulated were different (Zhao et al., 2001). It should also be 
A
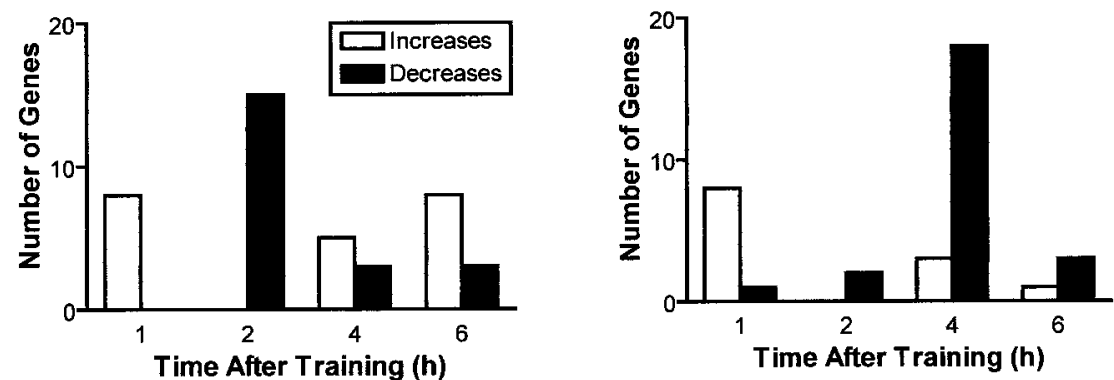

C

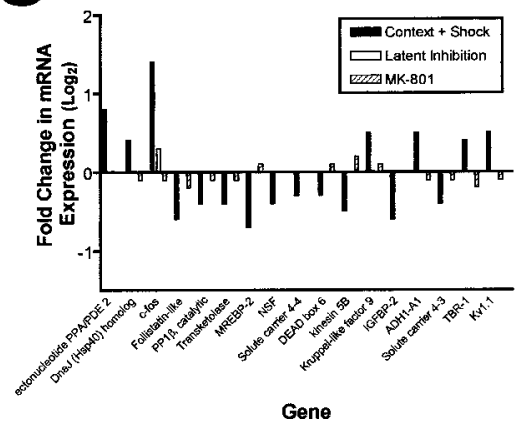

D

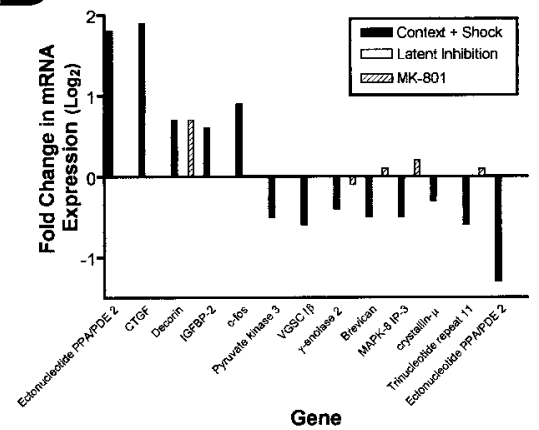

Figure 3. Changes in gene expression over time and lack of correlation with changes induced by stimuli that do not induce LTM. $A, B$, Changes in gene expression are grouped by time. Bars represent number of genes that were either upregulated (open) or downregulated (filled) at each time point. Note the initial surge in upregulation of gene expression ( $1 \mathrm{hr})$, followed by a decrease in gene expression (2-4hr). Data are plotted for CA1 $(A)$ and dentate gyrus $(B)$. C, Bar chart of changes in mRNA expression in area CA1 for genes in which data were collected for all three experimental conditions. Note that changes in gene expression observed in the paired training paradigm were not seen in either the unpaired or MK-801 control groups. D, Bar chart of changes in mRNA expression in the dentate gyrus for genes in which data were collected for all three experimental conditions. Note that changes in gene expression observed in the paired training paradigm were not seen in either the unpaired or MK-801 control groups except for decorin.

noted that levels of various transcription factors were regulated at discrete times throughout the time points investigated, including egr1/zif268, c-Fos, MREBP2 (metal regulatory element binding protein), various Kruppel-like factors, bHLH (basic helix-loophelix) factors, and Tbr-1 (T-box brain gene), suggesting that multiple waves of transcription are involved in consolidation of LTM (Bourtchouladze et al., 1998; Igaz et al., 2002).

This latter observation raises a question: if multiple waves of transcription are required for consolidation of LTM, then why is our list of consolidation-associated genes relatively small? Our procedure selects for changes in gene expression that are large and temporally synchronous between animals. Therefore, changes in gene expression associated with LTM consolidation that are subtle and/or not tightly regulated temporally have a low likelihood of detection using our methods.

Contextual fear conditioning involves exposure to stimuli that induce a variety of stress responses (Cahill, 2000). In a series of control experiments, expression of the putative consolidationassociated genes (supplementary Tables 1,2) was monitored after exposure of animals to an unpaired training paradigm (latent inhibition control). There were only two genes whose expression was similar between the paired and unpaired training paradigms. Levels of $18 \mathrm{~S}$ rRNA (GenBank accession number X00686) were repressed $6 \mathrm{hr}$ after fear conditioning in the dentate gyrus but were actually highly upregulated by the unpaired paradigm. In addition, an $\mathrm{Na}^{+} / \mathrm{K}^{+}$ATPase-like gene (GenBank accession number AW123952) displayed qualitatively similar regulation in both training paradigms. However, all other consolidationassociated genes ( 67 of 69 total genes) exhibited no change in expression after exposure to the unpaired training paradigm (Fig. $3 C, D$ ) (supplementary Tables 1,2 ). Therefore, genes identified by our screen were specifically regulated by the paired training paradigm that induces formation of long-term contextual fear memory (Fig. $1 B$ ).

Several unique genes were regulated in our unpaired training paradigm. These genes are most likely involved in aspects of latent inhibition. However, we are not reporting the changes in gene expression associated with the latent inhibition paradigm because we did not perform the appropriate control experiments for these studies, such as footshock alone or prolonged CS exposure alone. Additional investigation of latent inhibition-associated genes will form the basis of future experiments.

Formation and consolidation of contextual fear memories requires NMDAR function in the hippocampus (Fig. 1C) (Rampon et al., 2000; Shimizu et al., 2000; Stiedl et al., 2000). Moreover, some studies suggest that changes in gene expression attributable to LTM formation are also dependent on NMDAR function (Cammarota et al., 2000; Athos et al., 2002). Therefore, we investigated whether regulation of consolidation-associated genes occurred in the absence of NMDAR function. Before fear conditioning, animals received an intraperitoneal injection of the NMDAR antagonist MK-801. For these experiments, a different, custom-synthesized oligonucleotide array (Caltech 16K oligonucleotide array) was used, and, consequently, not all of the consolidation-associated genes were screened. Injection of MK-801 inhibited most regulation of gene expression (29 of 30 genes screened) associated with LTM consolidation (Fig. 3C,D). Only one gene exhibited quantitatively similar regulation after injection of MK-801: decorin (supplementary Tables 1,2). Regulation of decorin, or any gene, by exposure to a learning paradigm in the absence of NMDAR function may be attributable to activation of processes involved in LTM formation that are not dependent on either NMDAR function specifically or $\mathrm{Ca}^{2+}$ influx in general. Alternatively, increased decorin expression may be attributable to learning and memory-independent phenomena. Together, our results indicate that regulation of gene expression during LTM consolidation is dependent on NMDAR function, similar to the behavioral expression of memory (Fig. 1C). Furthermore, the lack of identical regulation of gene expression by the unpaired latent inhibition training protocol and in the absence of NMDAR function suggests that nearly all of the genes identified in our original screen are likely involved in some aspect of associative LTM consolidation.

Genes that are either coexpressed or coregulated have been found, in some cases, to be grouped together in the genome (Boutanaev et al., 2002; Roy et al., 2002). Within our set of genes that 
were regulated during LTM consolidation, there was significant grouping beyond what would be expected because of random chance (Fig. 4A) $\left(\chi_{(19)}^{2}=33 ; p<\right.$ $0.05)$. A chromosome was considered to have significant grouping if the percentage of genes found on that chromosome was more or less than the $95 \%$ confidence interval of the mean (Fig. $4 A$, dotted lines) (95\% confidence interval of $72-160 \%$ observed/expected). Significant grouping was seen on mouse chromosomes 10, 12, 16, 18, and 19 (Fig. 4A). Many of the genes found on chromosomes with significant grouping were immediate early transcription factors, growth factors, regulators of the actin cytoskeleton, or involved in MAPK signaling (supplementary Tables 1, 2).

To further investigate the significance of the consolidation-associated genes and their potential grouping with the genome, human homologs of the mouse genes were identified and mapped to the human genome. Of 69 consolidation-associated genes in the mouse, 66 human homologs were identified. When mapped onto the human genome, a significant amount of grouping of the consolidation-associated genes was observed (Fig. $4 B)\left(\chi_{(22)}^{2}=34 ; p<0.05\right)$. Again, several chromosomes had significantly more or less consolidation-associated genes present than the mean, as determined via $95 \%$ confidence intervals (Fig. $4 B$ ) (95\% confidence interval of $70-127 \%$ observed/expected).

Using the list of homologous human genes, we next investigated how many genes identified in our study were associated with either mental retardation or cognitive impairment. Surprisingly, 15 of the 66 human genes had already been implicated in a cognitive disorder (Fig. 4C, red arrows) (supplementary Table 3). Even more shocking was the observation that many of the consolidation-associated genes that were grouped together in the mouse were also grouped together in the human genome (Fig. $4 C$, blue circles). Almost all of the human chromosomes that had significant grouping of genes also contained clusters of comigrating murine genes. These results show that the expression profiling performed in the mouse detected several genes known to be involved in human cognition. Moreover, several of the murine genes appear to have comigrated within the human genome, suggesting a functional significance to the grouping of the genes within the genome.

Transcription factors modulate the ability of the RNA polymerase II holoenzyme to bind DNA and initiate transcription via binding to regulatory elements, which are short sequences of DNA found upstream of the transcription initiation site. We investigated which regulatory elements, if any, were enriched in our consolidation-associated gene dataset. We focused on regions 1 $\mathrm{kb}$ upstream of the transcription initiation site for each gene, where data were available. Each consolidation-associated gene had $\sim 70-100$ potential regulatory elements in the upstream region (data not shown) (Fig. 5E). We hypothesized that genes that were upregulated during LTM consolidation would contain regulatory elements distinct from those found in genes that were human.
Mouse

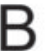

Human

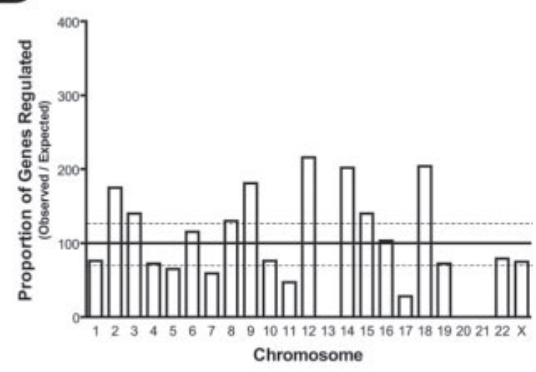

Figure 4. Regulation of gene expression is grouped by chromosome. Analysis of the changes in gene expression revealed a (he dotted lines indicate lower and upper $95 \%$ confidence intervals of the mean proportion of observed/expected inplicated in derangements of human memory or cognition. Green arrows indicate genes that have not yet been implicated in human cognitive disease. Blue circles indicate groups of genes that were present in the same chromosome in the mouse and the

downregulated. Only a few regulatory elements were shared among a significant number of genes (Fig. 5) (supplementary Tables 4, 5). Comparison of regulatory elements enriched in genes upregulated during LTM consolidation with those that were downregulated revealed little overlap (supplementary Tables 4,5 ), suggesting that regulatory elements identified in our analysis were specific for processes underlying consolidation of LTM and not elements conserved simply in a brain subregionselective manner. To further verify that the regulatory elements identified in our screen were not attributable to random chance, we screened for regulatory elements enriched in two sets of randomly selected genes (supplementary Table 6). The first set comprised genes that were expressed in the hippocampus but not regulated by fear conditioning. The second set comprised genes that were randomly selected from the oligonucleotide array but not regulated by fear conditioning. Subtracting regulatory elements that were present in either randomly generated list of genes resulted in elimination of a number of putative consolidationassociated transcription factors.

After filtering out regulatory elements that were not strictly memory consolidation associated, several regulatory elements still remained. In area CA1, a significant number of genes contained the regulatory element bound by C/EBP (supplementary Table 4), which has been implicated in formation of LTM (Alberini et al., 1994; Taubenfeld et al., 2001; Guan et al., 2002). In addition, many genes also contained the regulatory element for c-Rel (supplementary Table 4), a transcription factor of the NF- $\kappa \mathrm{B}$ (nuclear factor $\kappa \mathrm{B}$ ) family (Grilli and Memo, 1999; Liou and Hsia, 2003). In the dentate gyrus, several genes that were 

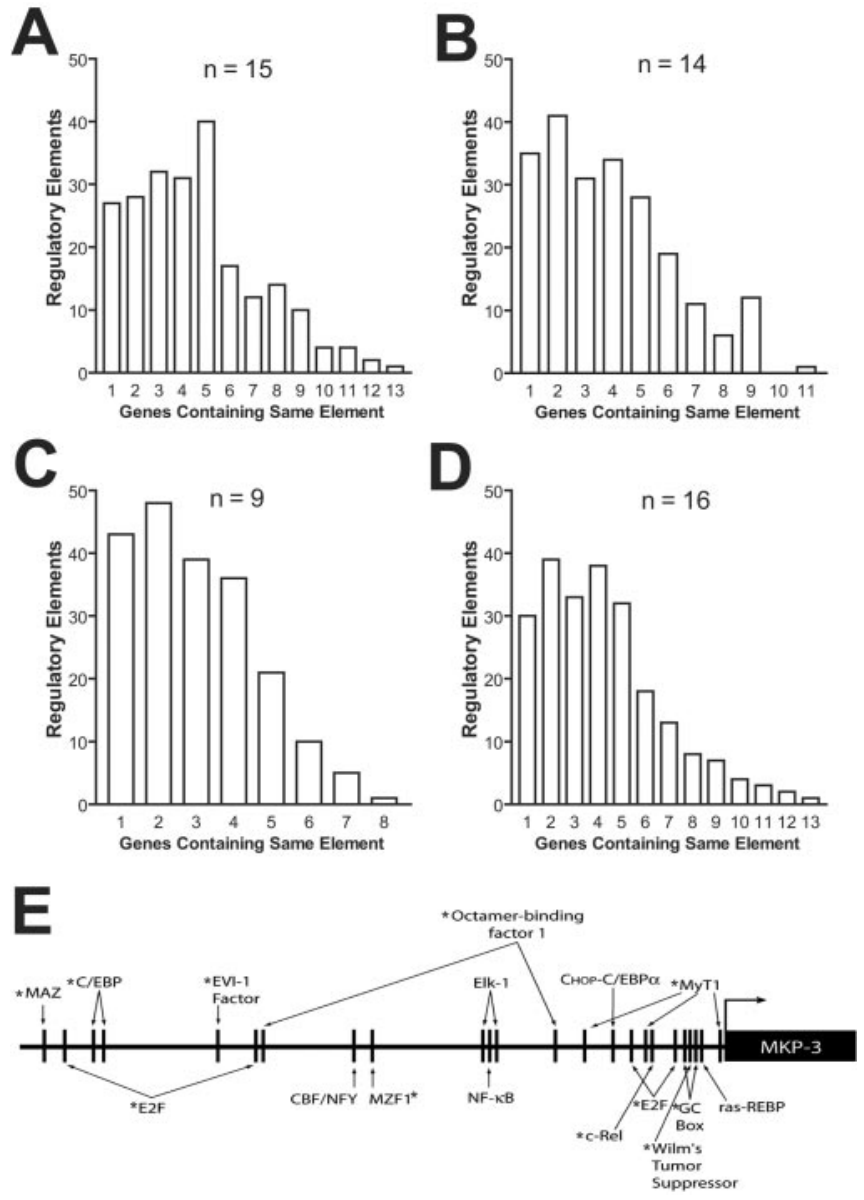

Figure 5. Presence of regulatory elements in the upstream region of genes involved in LTM consolidation. Upstream regions ( $1 \mathrm{~kb}$ ) of consolidation-associated genes were analyzed for the presence of potential regulatory elements. Plotted are the number of different regulatory elements versus the number of genes containing the respective regulatory elements. Numerous regulatory elements were identified; however, few regulatory elements were found in most or all genes analyzed in each group. For example, the first bar in $A$ indicates that 27 different regulatory elements were found exclusively upstream of only one gene, and the last bar in $A$ indicates that only one regulatory element (octamer binding protein 1) (supplementary Table 4) was present in 13 different genes (of a total of 15). $A$, CA1, Upregulation; $B, C A 1$, downregulation; $C$, dentate gyrus, upregulation; $D$, dentate gyrus, downregulation. Numbers in graphs indicate total number of genes in each group in which genomic upstream sequence data were available. E, Promoter region of MKP-3 (GenBank accession number Al845584). MKP-3 was upregulated in area CA1 $1 \mathrm{hr}$ after fear conditioning. The upstream region of MKP-3 contains 92 potential regulatory elements, and 10 of the 11 regulatory elements over-represented in the upstream regulatory regions of genes whose expression was upregulated during consolidation of LTM in area CA1. * indicates a regulatory element that was found to be significantly overrepresented in genes upregulated in area CA1 during consolidation of LTM (supplementary Table 4).

upregulated contained the AP-1 (activator protein 1) regulatory element (supplementary Table 5), which is the DNA binding site for the Fos/Jun family of transcription factors (Kaczmarek, 1993). This suggests that c-Fos plays a critical role in coordinating increases in gene expression related to LTM consolidation in the dentate gyrus. Although the upstream regions of many consolidation-associated genes in area CA1 had an AP-1 site, it was not significantly enriched by our criteria. Our results support previous studies implicating $\mathrm{C} / \mathrm{EBP}$ as critical for consolidation of LTM in area CA1 and suggests that c-Fos also plays a prominent role in hippocampal LTM consolidation. Finally, our results implicate a novel factor, c-Rel, in LTM formation.
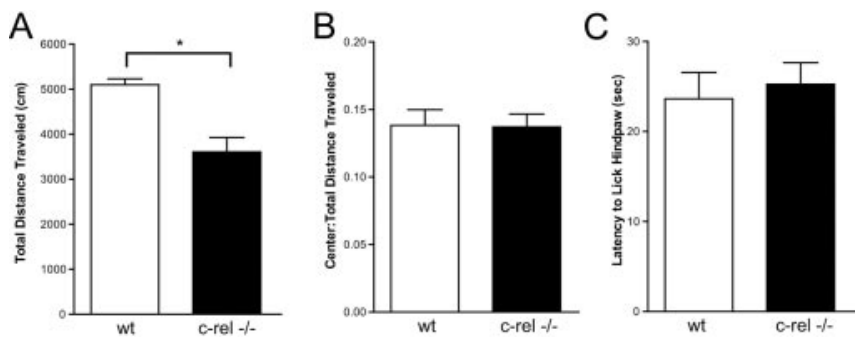

Figure 6. Behavioral characterization of ${\mathrm{c}-r e l^{-1-}}^{-}$mice. Basal behavioral characteristics of $\mathrm{c}-\mathrm{rel}^{-1-}$ mice were quantified. A, $\mathrm{crel}^{-/-}$animals $(n=9)$ were significantly hypoactive relative to WT animals $(n=9)$ during a 15 min session in the open-field task. $B$, No significant difference in the ratio of distance traveled in the center/total was seen, indicating that $c_{-r e l^{-1-}}$ mice have similar levels of basal anxiety relative to WT mice. C, No significant difference was seen in thermal sensitivity between WT $(n=9)$ and $c^{-r e l}{ }^{-1-}(n=9)$ animals, indicating that nociception is comparable between the two groups of mice. These results indicate that disruption of the c-re/ gene does not cause gross changes in basal behavioral characteristics of $\mathrm{C} 57 \mathrm{BL} / 6$ mice.

In a final series of experiments, the functional significance of one of the transcription factors identified in our bioinformatics screen was tested. There is good evidence that both $\mathrm{C} / \mathrm{EBP}$ (Taubenfeld et al., 2001; Chen et al., 2003) and c-Fos (Fleischmann et al., 2003) are important for formation of hippocampusdependent long-term memories, so we did not attempt to pursue these molecules. Instead, we investigated the performance of a c-rel knock-out mouse $\left(c-\mathrm{rel}^{-/-}\right)$(Liou et al., 1999) in several behavioral tasks to assess hippocampus-dependent memory function. First, $c$-rel mice were characterized in the open-field test, which measures baseline locomotor behavior and provides an index of anxiety. $c$-rel animals were significantly hypoactive (Fig. 6A) $(t=4.3$; df $=16 ; p<0.001)$ but showed no significant difference in center/total distance ratios (Fig. $6 B)(t=0.08 ; \mathrm{df}=$ 16 ; $p<1.0)$. These results indicate that $c$-rel mice are less active but not any more or less anxious than normal mice.

To assess nociception in $c$-rel ${ }^{-1-}$ mice, the thermal sensitivity test was performed. Animals were placed on a precision hotplate that was maintained at $53^{\circ} \mathrm{C}$, and latency to lick hindpaw was recorded. There was no significant difference between normal and $c-r e l^{-1-}$ mice (Fig. 6C) $(t=0.4 ; \mathrm{df}=17 ; p<0.7)$. Therefore, $c-r e l^{-/-}$mice appear to perceive noxious stimuli equally well to normal mice.

Hippocampus-dependent memory was assessed in $\mathrm{c}-\mathrm{rel}^{-/-}$ mice via two different fear conditioning paradigms. The first paradigm was an associative, cued conditioning paradigm that consisted of two pairings of a $30 \mathrm{sec}$ white-noise cue with a $1 \mathrm{sec}$ electric shock. Freezing behavior was assessed during and $24 \mathrm{hr}$ after training. This experimental paradigm tests amygdala function. No significant differences in freezing behavior were observed during the training session (Fig. 7A) $(t=1.7$; df $=5 ; p<$ 0.2 ), suggesting no differences in perception of and response to the footshock. In addition, freezing behavior $24 \mathrm{hr}$ after the training session was not significantly different between $\mathrm{c}^{-\mathrm{rel}^{-1-}}$ and normal animals before (Fig. $7 B)(q=2.4$; df $=5 ; p<0.2)$ or during presentation of the cue (Fig. $7 B)(q=0.01 ; \mathrm{df}=5 ; p<0.5)$. Together, these results indicate that amygdala-dependent long-term memory formation is unaffected in $\mathrm{c}-\mathrm{rel}^{-/-}$animals. Because the amygdala is vital to the formation of all fear-dependent memories, these results allow for straightforward interpretation of contextdependent fear conditioning experiments.

To assess whether c-rel was important in the formation of hippocampus-dependent memories, animals were exposed to the contextual fear conditioning paradigm used in the initial expres- 
A

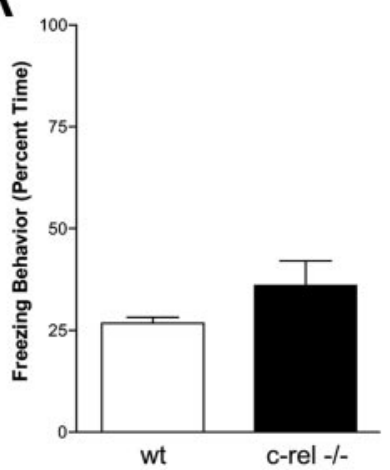

$B$

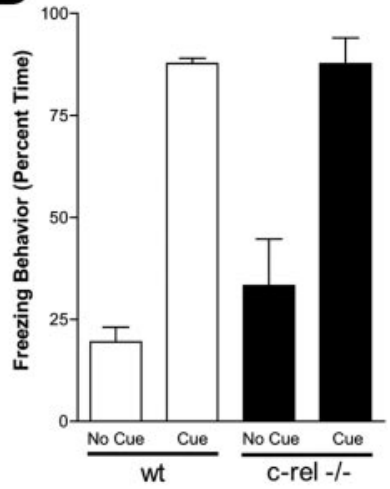

○

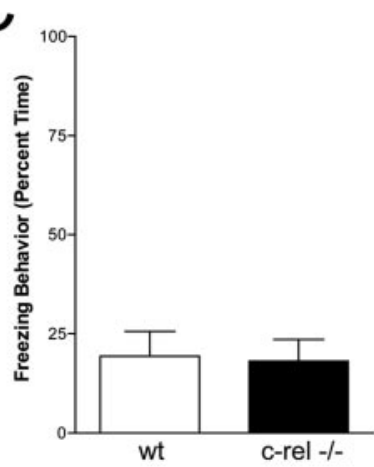

D

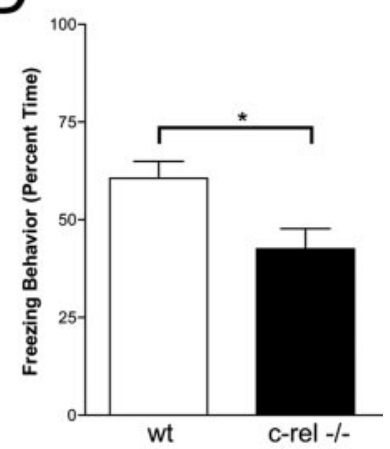

Figure 7. $\quad c_{-r e l}{ }^{-/-}$animals have impaired contextual, but not associative, fear memory. WT and $c-\mathrm{rel}^{-1-}$ animals were exposed to either an associative $(A, B)$ or contextual $(C, D)$ fear conditioning paradigm. Freezing behavior was assessed during $(A, C)$ or $24 \mathrm{hr}$ after $(B, D)$ training. $A$, No significant difference was seen in freezing behavior between WT $(n=4)$ or $^{-r^{-} l^{-1-}}$ $(n=3)$ mice during associative fear conditioning training. $B$, No significant differences were seen in freezing behavior when mice were tested $24 \mathrm{hr}$ later in the absence and presence of the auditory cue. $C$, No significant difference was seen between WT $(n=5)$ or c-rel $^{-1-}(n=6)$ animals during contextual fear conditioning training. $D, \mathrm{Crel}^{-1-}$ animals had a significant deficit in freezing behavior assessed $24 \mathrm{hr}$ after training in the training context. These results indicate that $\mathrm{c}-\mathrm{rel}^{-1-}$ animals have a specific deficit in hippocampus-dependent long-term memory formation.

sion profiling studies. This paradigm consists of three shocks administered to the animal in a novel context. Freezing behavior was measured during and $24 \mathrm{hr}$ after training. There were no significant differences in freezing behavior between $\mathrm{c}_{\text {- }} \mathrm{Cl}^{-/-}$and normal animals during the training session (Fig. $7 C)(t=0.1$; $\mathrm{df}=9 ; p<0.9)$, indicating that the animals perceived and responded to the electric shocks in similar manners. However, there was a highly significant difference in freezing behavior when ${\mathrm{c}-\mathrm{rel}^{-/-}}^{-}$animals were placed into the training context $24 \mathrm{hr}$ later (Fig. 7D) $(t=2.6 ; \mathrm{df}=9 ; p<0.05)$. These results indicate that hippocampus-dependent memory formation is deficient in $\mathrm{c}^{-\mathrm{rel}^{-/-}}$animals. Furthermore, these results validate our bioinformatics approach to understanding the genomic basis of longterm memory consolidation in the hippocampus.

\section{Discussion}

For several decades, it has been appreciated that regulation of gene expression is a general requirement for the formation of long-term memory (Abel and Kandel, 1998; Milner et al., 1998). In addition, a great deal of progress has been made elucidating the signaling mechanisms responsible for initiating the processes involved in the regulation of gene expression required for longterm memory formation (Atkins et al., 1998; Adams and Sweatt,

2002). Our data and that of others indicate that expression of even a single gene represents the integrated action of numerous signaling pathways (Buchler et al., 2003). Surprisingly, little is known about the actual integration of signaling at the level of gene expression in the context of long-term memory formation. The present study begins to fill this gap by combining RNA expression profiling of LTM consolidation in the hippocampus with a bioinformatics approach to identifying the cis-regulatory elements engaged during LTM consolidation. Several new candidate regulatory elements and signaling pathways were identified that have never before been implicated in consolidation of LTM.

Although our analyses do not depend on the specific identity of the genes found to be regulated during consolidation of LTM, examination of our set of consolidation-associated genes reveals many similarities with other reports on regulation of gene expression during induction of either synaptic plasticity or memory formation. The most notable of similarities are the regulation of the immediate early transcription factors $c$-fos and egrl/zif268 (early growth response/zinc finger protein) (Cole et al., 1989; Abraham et al., 1991; Guzowski et al., 2001; Ressler et al., 2002). In addition, several recent studies have begun to implicate regulation of transthyretin in memory formation and derangements thereof (Stork et al., 2001; Stein and Johnson, 2002). Another gene we identified, the trinucleotide repeat-containing gene 11 (GenBank accession number AF071310), may be associated with X-linked mental retardation (Philibert et al., 1998). In the area of signaling, we identified the MKP-3 (MAPK phosphatase)/PYST1 phosphatase as a consolidation-associated gene, which may be activated in response to ERK/MAPK signaling that would occur early during induction of LTM formation (Qian et al., 1994; Camps et al., 2000; Adams and Sweatt, 2002). Moreover, the overall types of genes that were regulated in our study are very similar to other more limited expression profiling studies in different brain areas (Stork et al., 2001; Cavallaro et al., 2002; Leil et al., 2002). Specifically, genes involved in regulation of transcription, signaling, growth, metabolism, extracellular matrix, and cell structure were regulated. These parallels provide validation that our techniques have identified consolidation-associated gene regulation. Moreover, our results have identified several new candidate consolidation-associated genes.

The relevance to memory formation, and possibly human cognition, of the genes identified in our screen becomes apparent when the human homologs of the murine genes are examined. Nearly $25 \%$ of the genes identified in our screen have already been associated with derangements in either memory or cognition in humans (supplementary Table 3). Moreover, the relative genomic positions of many of the murine genes appear to be conserved in the human genome (Fig. $4 C$ ). An intriguing possibility is that many of the genes identified in our screen lie in putative human mental retardation loci but have yet to be identified.

One of the largest concerns when dealing with data from experiments using high-density microarrays is the specificity of the changes observed with the experimental treatments. The present study was designed to minimize nonspecific changes in gene expression. First, all experiments detailing changes in gene expression during consolidation of LTM were performed three independent times. This allowed for filtering of the resulting list of genes by variance, greatly increasing the power of the statistical analyses performed. As a result, several hundred genes that had large mean changes in expression were not included in our list, or the statistical analysis, because of high variability. Second, the specificity of the changes in gene expression were confirmed by performing experiments in which no long-term contextual fear 
memory was formed: the latent inhibition and MK-801 controls. Very few of the changes observed in the paired training paradigm, in which the animals successfully formed contextual fear memory, were observed in the latent inhibition or MK-801 controls, in which the animals did not form contextual fear memory. Furthermore, there were actually very few statistically significant changes in gene expression in the latent inhibition and MK-801 controls, confirming that the overall procedures used in the present study have been calibrated such that artifactual false positive changes in gene expression do not appear to be a major problem (Choi et al., 2001).

Some differences between the genes identified in our and other studies do exist. Perhaps the most striking difference is an apparent lack of regulation of the messages for Arc (Lyford et al., 1995) and Homer (Brakeman et al., 1997), which are dramatically increased by synaptic activity. Another difference between our study and other published reports is a lack of $\mathrm{C} / \mathrm{EBP}-\beta$ regulation (Yukawa et al., 1998). These differences can be explained by accounting for time of sampling and genes present on our microarrays. A probe for Arc is not present on the microarray used in our study (Affymetrix U74Av2). In the case of Homer, the increase in mRNA expression occurs early and does not persist for long periods of time (Brakeman et al., 1997). In addition, sustained increases in levels of C/EBP- $\beta$ and C/EBP- $\delta$ mRNA are not apparent until $9 \mathrm{hr}$ after a learning event (Taubenfeld et al., 2001). Therefore, our studies do not rule out regulation of Arc, Homer, or C/EBP either before $1 \mathrm{hr}$ or later than $6 \mathrm{hr}$ after fear conditioning (Fig. 1A).

During analysis of the regulatory elements found to be enriched in the consolidation-associated genes, it was surprising to find that the CRE (CREB) (Athos et al., 2002) and SRE (serum response element) [Elk-1/SRF (Ets-like transcription factor/serum response factor)] (Cammarota et al., 2000) regulatory elements, which have been implicated previously in formation of LTM, were not significantly enriched in our consolidationassociated genes. These regulatory elements were present in approximately half of the genes that were regulated in our study (supplementary Tables 4, 5). Several reasons could account for the lack of specific enrichment of these regulatory elements in our dataset. Our studies may have missed the specific time domain that these factors are active. Another possibility is that these regulatory elements may be important in regulating only a specific subset of genes involved in LTM consolidation. A final possibility is that regulation of gene expression during consolidation of LTM is attributable to the coordinate action of many transcription factors. Therefore, the expression of any one gene likely reflects the integrated action of many different regulatory elements on transcription (Fig. 5E). For example, in a study by Impey et al. (1996), most (five of eight) founder strains of transgenic mice with CRE-lacZ reporter constructs exhibited no change in CREmediated transcription in response to vigorous stimulation of the cAMP signaling pathway. Moreover, among the strains that did show increased CRE-mediated transcription in response to activation of the CAMP signaling cascade, there was significant variability in the magnitude of response between founder strains (Impey et al., 1996). These findings suggest that the efficacy of the reporter construct was affected by the surrounding genomic context, an interpretation in keeping with our observations. Regardless, our results highlight a current gap in the understanding of the molecular processes involved in LTM formation: specifically, what transcription factors are involved in coordinating gene expression for successful LTM consolidation. Furthermore, our results suggest that several transcription factors that have been heretofore overlooked in LTM consolidation should be considered.

The importance of investigating the potential role that new transcription factors might play in memory formation is echoed with our finding that c-Rel, a transcription factor identified in the bioinformatics analysis of our dataset, is involved in hippocampus-dependent long-term memory formation (Fig. 7). Previously, activation of c-Rel was linked to neuronal protection within the hippocampus (Pizzi et al., 2002), which provided some of the first evidence that c-Rel signaling within the hippocampus might play an important role in regulating neuronal physiology. Our studies extend these observations and demonstrate that c-Rel plays a role in hippocampal long-term memory formation. These results suggest a selective involvement of NF- $\kappa \mathrm{B}$ factors in distinct brain functions. Moreover, the results from the $\mathrm{c}$-rel ${ }^{-1-}$ mouse model serve to validate the template of a genome-centric bioinformatics approach to analysis of large-scale expression profiling datasets. Our study used the molecular readout provided by oligonucleotide arrays to deduce new nuclear signaling pathways involved in consolidation of LTM. Once these pathways were revealed, we tested and verified one of the ultimate predictions of our study: that $c$-rel is important in LTM consolidation.

It has long been appreciated that consolidation of LTM is dependent on de novo synthesis of mRNA and protein. Our study has begun to investigate patterns of gene expression at several different levels. First, we have begun to comprehensively describe what genes and how many are robustly regulated during consolidation of LTM. Second, we identified regulatory elements that are enriched in the genes regulated during LTM consolidation. This will allow for more precise investigation of the transcription factors and signaling pathways involved in LTM consolidation and will begin to elucidate the genomic program engaged by induction of LTM formation. Finally, we demonstrated that one of the transcription factors identified in our screen, c-Rel, is important for hippocampus-dependent long-term memory formation. Our results will provide a template for future investigations examining the molecular basis of memory formation and should prove to be valuable in understanding, and possibly developing new treatments for, cognitive dysfunction.

\section{References}

Abel T, Kandel E (1998) Positive and negative regulatory mechanisms that mediate long-term memory storage. Brain Res Brain Res Rev 26:360-378.

Abraham WC, Dragunow M, Tate WP (1991) The role of immediate early genes in the stabilization of long-term potentiation. Mol Neurobiol 5:297-314.

Accetta SG, Abeche AM, Buchabqui JA, Hammes L, Pratti R, Afler T, Capp E (2002) Memory loss and ataxia after hyperemesis gravidarum: a case of Wernicke-Korsakoff syndrome. Eur J Obstet Gynecol Reprod Biol 102:100-101.

Adams JP, Sweatt JD (2002) Molecular psychology: roles for the ERK MAP kinase cascade in memory. Annu Rev Pharmacol Toxicol 42:135-163.

Alberini CM, Ghirardi M, Metz R, Kandel ER (1994) C/EBP is an immediate-early gene required for the consolidation of long-term facilitation in Aplysia. Cell 76:1099-1114.

Athos J, Impey S, Pineda VV, Chen X, Storm DR (2002) Hippocampal CREmediated gene expression is required for contextual memory formation. Nat Neurosci 5:1119-1120.

Atkins CM, Selcher JC, Petraitis JJ, Trzaskos JM, Sweatt JD (1998) The MAPK cascade is required for mammalian associative learning. Nat Neurosci 1:602-609.

Bajo M, Fruehauf J, Kim SH, Fountoulakis M, Lubec G (2002) Proteomic evaluation of intermediary metabolism enzyme proteins in fetal Down's syndrome cerebral cortex. Proteomics 2:1539-1546.

Benjamini Y, Drai D, Elmer G, Kafkafi N, Golani I (2001) Controlling the 
false discovery rate in behavior genetics research. Behav Brain Res 125:279-284.

Beyer KS, Klauck SM, Benner A, Poustka F, Poustka A (2002) Association studies of the HOPA dodecamer duplication variant in different subtypes of autism. Am J Med Genet 114:110-115.

Bourtchuladze R, Frenguelli B, Blendy J, Cioffi D, Schutz G, Silva AJ (1994) Deficient long-term memory in mice with a targeted mutation of the cAMP-responsive element-binding protein. Cell 79:59-68.

Bourtchouladze R, Abel T, Berman N, Gordon R, Lapidus K, Kandel ER (1998) Different training procedures recruit either one or two critical periods for contextual memory consolidation, each of which requires protein synthesis and PKA. Learn Mem 5:365-374.

Boutanaev AM, Kalmykova AI, Shevelyov YY, Nurminsky DI (2002) Large clusters of co-expressed genes in the Drosophila genome. Nature 420:666-669.

Brakebusch C, Seidenbecher CI, Asztely F, Rauch U, Matthies H, Meyer H, Krug M, Bockers TM, Zhou X, Kreutz MR, Montag D, Gundelfinger ED, Fassler R (2002) Brevican-deficient mice display impaired hippocampal CA1 long-term potentiation but show no obvious deficits in learning and memory. Mol Cell Biol 22:7417-7427.

Brakeman PR, Lanahan AA, O'Brien R, Roche K, Barnes CA, Huganir RL, Worley PF (1997) Homer: a protein that selectively binds metabotropic glutamate receptors. Nature 386:284-288.

Buchler NE, Gerland U, Hwa T (2003) On schemes of combinatorial transcription logic. Proc Natl Acad Sci USA 100:5136-5141.

Burk K, Globas C, Bosch S, Graber S, Abele M, Brice A, Dichgans J, Daum I, Klockgether T (1999) Cognitive deficits in spinocerebellar ataxia 2. Brain 122:769-777.

Cahill L (2000) Neurobiological mechanisms of emotionally influenced, long-term memory. Prog Brain Res 126:29-37.

Cammarota M, Bevilaqua LR, Ardenghi P, Paratcha G, Levi de Stein M, Izquierdo I, Medina JH (2000) Learning-associated activation of nuclear MAPK, CREB and Elk-1, along with Fos production, in the rat hippocampus after a one-trial avoidance learning: abolition by NMDA receptor blockade. Brain Res Mol Brain Res 76:36-46.

Camps M, Nichols A, Arkinstall S (2000) Dual specificity phosphatases: a gene family for control of MAP kinase function. FASEB J 14:6-16.

Cavallaro S, D’Agata V, Manickam P, Dufour F, Alkon DL (2002) Memoryspecific temporal profiles of gene expression in the hippocampus. Proc Natl Acad Sci USA 99:16279-16284.

Chen A, Muzzio IA, Malleret G, Bartsch D, Verbitsky M, Pavlidis P, Yonan AL, Vronskaya S, Grody MB, Cepeda I, Gilliam TC, Kandel ER (2003) Inducible enhancement of memory storage and synaptic plasticity in transgenic mice expressing an inhibitor of ATF4 (CREB-2) and C/EBP proteins. Neuron 39:655-669.

Choi S, Hao W, Chen CK, Simon MI (2001) Gene expression profiles of light-induced apoptosis in arrestin/rhodopsin kinase-deficient mouse retinas. Proc Natl Acad Sci USA 98:13096-13101.

Cole AJ, Saffen DW, Baraban JM, Worley PF (1989) Rapid increase of an immediate early gene messenger RNA in hippocampal neurons by synaptic NMDA receptor activation. Nature 340:474-476.

Edgar R, Domrachev M, Lash AE (2002) Gene expression omnibus: NCBI gene expression and hybridization array data repository. Nucleic Acids Res 30:207-210.

Fanselow MS (2000) Contextual fear, gestalt memories, and the hippocampus. Behav Brain Res 110:73-81.

Fanselow MS, Kim JJ, Yipp J, De Oca B (1994) Differential effects of the $N$-methyl-D-aspartate antagonist DL-2-amino-5-phosphonovalerate on acquisition of fear of auditory and contextual cues. Behav Neurosci 108:235-240.

Fleischmann A, Hvalby O, Jensen V, Strekalova T, Zacher C, Layer LE, Kvello A, Reschke M, Spanagel R, Sprengel R, Wagner EF, Gass P (2003) Impaired long-term memory and NR2A-type NMDA receptor-dependent synaptic plasticity in mice lacking c-Fos in the CNS. J Neurosci 23:9116-9122.

Genoux D, Haditsch U, Knobloch M, Michalon A, Storm D, Mansuy IM (2002) Protein phosphatase 1 is a molecular constraint on learning and memory. Nature 418:970-975.

Grilli M, Memo M (1999) Nuclear factor-kappaB/Rel proteins: a point of convergence of signalling pathways relevant in neuronal function and dysfunction. Biochem Pharmacol 57:1-7.

Guan Z, Giustetto M, Lomvardas S, Kim JH, Miniaci MC, Schwartz JH,
Thanos D, Kandel ER (2002) Integration of long-term-memory-related synaptic plasticity involves bidirectional regulation of gene expression and chromatin structure. Cell 111:483-493.

Guzowski JF, Setlow B, Wagner EK, McGaugh JL (2001) Experiencedependent gene expression in the rat hippocampus after spatial learning: a comparison of the immediate-early genes Arc, c-fos, and zif268. J Neurosci 21:5089-5098.

Hall J, Thomas KL, Everitt BJ (2001) Cellular imaging of zif268 expression in the hippocampus and amygdala during contextual and cued fear memory retrieval: selective activation of hippocampal CA1 neurons during the recall of contextual memories. J Neurosci 21:2186-2193.

Igaz LM, Vianna MR, Medina JH, Izquierdo I (2002) Two time periods of hippocampal mRNA synthesis are required for memory consolidation of fear-motivated learning. J Neurosci 22:6781-6789.

Impey S, Mark M, Villacres EC, Poser S, Chavkin C, Storm DR (1996) Induction of CRE-mediated gene expression by stimuli that generate longlasting LTP in area CA1 of the hippocampus. Neuron 16:973-982.

Impey S, Smith DM, Obrietan K, Donahue R, Wade C, Storm DR (1998) Stimulation of CRE-mediated transcription during contextual learning. Nat Neurosci 1:595-601.

Irwin LN (2001) Gene expression in the hippocampus of behaviorally stimulated rats: analysis by DNA microarray. Brain Res Mol Brain Res 96:163-169.

Kaczmarek L (1993) Molecular biology of vertebrate learning: is c-fos a new beginning? J Neurosci Res 34:377-381.

Leil TA, Ossadtchi A, Cortes JS, Leahy RM, Smith DJ (2002) Finding new candidate genes for learning and memory. J Neurosci Res 68:127-137.

Liou HC, Hsia CY (2003) Distinctions between c-Rel and other NF-kappaB proteins in immunity and disease. BioEssays 25:767-780.

Liou HC, Jin Z, Tumang J, Andjelic S, Smith KA, Liou ML (1999) c-Rel is crucial for lymphocyte proliferation but dispensable for $\mathrm{T}$ cell effector function. Int Immunol 11:361-371.

Lyford GL, Yamagata K, Kaufmann WE, Barnes CA, Sanders LK, Copeland NG, Gilbert DJ, Jenkins NA, Lanahan AA, Worley PF (1995) Arc, a growth factor and activity-regulated gene, encodes a novel cytoskeletonassociated protein that is enriched in neuronal dendrites. Neuron 14:433-445.

Matzilevich DA, Rall JM, Moore AN, Grill RJ, Dash PK (2002) High-density microarray analysis of hippocampal gene expression following experimental brain injury. J Neurosci Res 67:646-663.

Meiri N, Ghelardini C, Tesco G, Galeotti N, Dahl D, Tomsic D, Cavallaro S, Quattrone A, Capaccioli S, Bartolini A, Alkon DL (1997) Reversible antisense inhibition of Shaker-like Kv1.1 potassium channel expression impairs associative memory in mouse and rat. Proc Natl Acad Sci USA 94:4430-4434.

Milner B, Squire LR, Kandel ER (1998) Cognitive neuroscience and the study of memory. Neuron 20:445-468.

Mody M, Cao Y, Cui Z, Tay KY, Shyong A, Shimizu E, Pham K, Schultz P, Welsh D, Tsien JZ (2001) Genome-wide gene expression profiles of the developing mouse hippocampus. Proc Natl Acad Sci USA 98:8862-8867.

Narisawa-Saito M, Iwakura Y, Kawamura M, Araki K, Kozaki S, Takei N, Nawa H (2002) Brain-derived neurotrophic factor regulates surface expression of alpha-amino-3-hydroxy-5-methyl-4-isoxazoleproprionic acid receptors by enhancing the N-ethylmaleimide-sensitive factor/ GluR2 interaction in developing neocortical neurons. J Biol Chem 277:40901-40910.

Philibert RA, King BH, Winfield S, Cook EH, Lee YH, Stubblefield B, Damschroder-Williams P, Dea C, Palotie A, Tengstrom C, Martin BM, Ginns EI (1998) Association of an X-chromosome dodecamer insertional variant allele with mental retardation. Mol Psychiatry 3:303-309.

Phillips RG, LeDoux JE (1992) Differential contribution of amygdala and hippocampus to cued and contextual fear conditioning. Behav Neurosci 106:274-285.

Pizzi M, Goffi F, Boroni F, Benarese M, Perkins SE, Liou HC, Spano P (2002) Opposing roles for NF-kappa B/Rel factors p65 and c-Rel in the modulation of neuron survival elicited by glutamate and interleukin-1beta. J Biol Chem 277:20717-20723.

Qian Z, Gilbert M, Kandel ER (1994) Temporal and spatial regulation of the expression of BAD2, a MAP kinase phosphatase, during seizure, kindling, and long-term potentiation. Learn Mem 1:180-188.

Rampon C, Tang YP, Goodhouse J, Shimizu E, Kyin M, Tsien JZ (2000) Enrichment induces structural changes and recovery from nonspatial 
memory deficits in CA1 NMDAR1-knockout mice. Nat Neurosci 3:238-244.

Ressler KJ, Paschall G, Zhou XL, Davis M (2002) Regulation of synaptic plasticity genes during consolidation of fear conditioning. J Neurosci 22:7892-7902.

Roy PJ, Stuart JM, Lund J, Kim SK (2002) Chromosomal clustering of muscle-expressed genes in Caenorhabditis elegans. Nature 418:975-979.

Santin LJ, Aguirre JA, Rubio S, Begega A, Miranda R, Arias JL (2003) c-Fos expression in supramammillary and medial mammillary nuclei following spatial reference and working memory tasks. Physiol Behav 78:733-739.

Schwarzman AL, Gregori L, Vitek MP, Lyubski S, Strittmatter WJ, Enghilde JJ, Bhasin R, Silverman J, Weisgraber KH, Coyle PK, Zagorski MG, Talafous J, Eisenberg M, Saunders AM, Roses AD, Goldgaber D (1994) Transthyretin sequesters amyloid beta protein and prevents amyloid formation. Proc Natl Acad Sci USA 91:8368-8372.

Schweiger S, Foerster J, Lehmann T, Suckow V, Muller YA, Walter G, Davies T, Porter H, van Bokhoven H, Lunt PW, Traub P, Ropers HH (1999) The Opitz syndrome gene product, MID1, associates with microtubules. Proc Natl Acad Sci USA 96:2794-2799.

Shimizu E, Tang YP, Rampon C, Tsien JZ (2000) NMDA receptordependent synaptic reinforcement as a crucial process for memory consolidation. Science 290:1170-1174.

Silva AJ (2003) Molecular and cellular cognitive studies of the role of synaptic plasticity in memory. J Neurobiol 54:224-237.

Snow AD, Mar H, Nochlin D, Kresse H, Wight TN (1992) Peripheral distribution of dermatan sulfate proteoglycans (decorin) in amyloidcontaining plaques and their presence in neurofibrillary tangles of Alzheimer's disease. J Histochem Cytochem 40:105-113.

Stein TD, Johnson JA (2002) Lack of neurodegeneration in transgenic mice overexpressing mutant amyloid precursor protein is associated with in- creased levels of transthyretin and the activation of cell survival pathways. J Neurosci 22:7380-7388.

Stiedl O, Birkenfeld K, Palve M, Spiess J (2000) Impairment of conditioned contextual fear of C57BL/6J mice by intracerebral injections of the NMDA receptor antagonist APV. Behav Brain Res 116:157-168.

Stork O, Stork S, Pape HC, Obata K (2001) Identification of genes expressed in the amygdala during the formation of fear memory. Learn Mem 8:209-219.

Taubenfeld SM, Wiig KA, Monti B, Dolan B, Pollonini G, Alberini CM (2001) Fornix-dependent induction of hippocampal CCAAT enhancerbinding protein $\beta$ and $\delta$ co-localizes with phosphorylated CREB and accompanies long-term memory consolidation. J Neurosci 21:84-91.

Tsai KJ, Chen SK, Ma YL, Hsu WL, Lee EH (2002) sgk, a primary glucocorticoid-induced gene, facilitates memory consolidation of spatial learning in rats. Proc Natl Acad Sci USA 99:3990-3995.

Ueberham U, Ueberham E, Gruschka H, Arendt T (2003) Connective tissue growth factor in Alzheimer's disease. Neuroscience 116:1-6.

Wei F, Xu ZC, Qu Z, Milbrandt J, Zhuo M (2000) Role of EGR1 in hippocampal synaptic enhancement induced by tetanic stimulation and amputation. J Cell Biol 149:1325-1334.

Williams JM, Guevremont D, Kennard JT, Mason-Parker SE, Tate WP, Abraham WC (2003) Long-term regulation of $N$-methyl-D-aspartate receptor subunits and associated synaptic proteins following hippocampal synaptic plasticity. Neuroscience 118:1003-1013.

Yukawa K, Tanaka T, Tsuji S, Akira S (1998) Expressions of CCAAT/ enhancer-binding proteins beta and delta and their activities are intensified by cAMP signaling as well as $\mathrm{Ca}^{2+} /$ calmodulin kinases activation in hippocampal neurons. J Biol Chem 273:31345-31351.

Zhao X, Lein ES, He A, Smith SC, Aston C, Gage FH (2001) Transcriptional profiling reveals strict boundaries between hippocampal subregions. J Comp Neurol 441:187-196. 